\title{
Vulnerability of the Ancient Peat Plateaus in Western Siberia
}

\author{
Alexander Pastukhov ${ }^{1, * \mathbb{D}}$, Tatiana Marchenko-Vagapova ${ }^{2}$, Sergey Loiko ${ }^{3} \mathbb{D}$ and Dmitry Kaverin $^{1}$ \\ 1 Institute of Biology Komi Science Centre Ural Branch Russian Academy of Sciences, Kommunisticheskaya 28, \\ 167982 Syktyvkar, Russia; dkav@mail.ru \\ 2 Institute of Geology Komi Science Centre Ural Branch Russian Academy of Sciences, Pervomaiskaya 54, \\ 167982 Syktyvkar, Russia; timarchenko@mail.ru \\ 3 BIO-GEO-CLIM Laboratory, National Research Tomsk State University, Lenina 36, 634050 Tomsk, Russia; \\ s.loyko@yandex.ru \\ * Correspondence: alpast@mail.ru; Tel.: +7-999-295-1109
}

Citation: Pastukhov, A.;

Marchenko-Vagapova, T.; Loiko, S.;

Kaverin, D. Vulnerability of the Ancient Peat Plateaus in Western Siberia. Plants 2021, 10, 2813. https://doi.org/10.3390/ plants10122813

Academic Editor: Milan S. Stankovic

Received: 19 October 2021

Accepted: 16 December 2021

Published: 19 December 2021

Publisher's Note: MDPI stays neutral with regard to jurisdictional claims in published maps and institutional affiliations.

Copyright: (c) 2021 by the authors. Licensee MDPI, Basel, Switzerland. This article is an open access article distributed under the terms and conditions of the Creative Commons Attribution (CC BY) license (https:// creativecommons.org/licenses/by/ $4.0 /)$.

\begin{abstract}
Based on the data of the plant macrofossil and palynological composition of the peat deposits, the evolution and current state of polygonal peatlands were analyzed at the southern limit of continuous permafrost in the Pur-Taz interfluve. Paleoreconstruction shows that peat accumulation began in the Early Holocene, about 9814 cal. year BP, in the Late Pre-Boreal (PB2 ), at a rate of 1 to $1.5 \mathrm{~mm}_{\text {year }}{ }^{-1}$. Intensive peat accumulation continued in the Boreal and early Atlantic. The geocryological complex of polygonal peatlands has remained a stable bog system despite the predicted warming and increasing humidity. However, a rather rapid upper permafrost degradation and irreversible changes in the bog systems of polygonal peatlands occur with anthropogenic disturbances, in particular, a change in the natural hydrological regime under construction of linear objects.
\end{abstract}

Keywords: cryolithozone; degradation; bogs; arctic peatlands; permafrost; soil-geocryological complex; palynological spectra; macrofossil composition; georadar survey

\section{Introduction}

Peatlands, occupying only $3 \%$ of the land surface, contain about $15-30 \%$ of global soil organic carbon reserves [1], thereby playing a significant role in the regulation of general planetary processes, such as biogeochemical and biogeophysical cycles, greenhouse gases, and activity and species diversity of vegetation and soil biota. In Western Siberia, peatlands cover $592,440 \mathrm{~km}^{2}$, exceeding $50 \%$ of all regional area in the taiga zone, and have the peat thickness up to 8-10 m [2]. The Western Siberian Plain stands out among other boreal plains by phenomenal bogging, which has both global and regional significance. The polygonal peatlands and peat plateaus are the most extensive bog types in the study area [3]. However, in the tundra, polygonal peatlands with a thick peat deposit (from 2 to $5 \mathrm{~m}$ and more) are not uncommon [3-5].

Current climate warming and wetting in Siberia led to a lake area increase by $0.89 \%$ detected for the 1999-2013 period and an increase by 4.15\% for the 1999-2018 period. In Eastern Siberia, a lake area expansion trend was detected in high yedoma fraction areas, indicating ongoing Yedoma degradation by lake thermokarst [6]. In western Siberia, climate warming, increased precipitation, and permafrost thaw are also accompanied by an increase in the frequency of full or partial drainage of thermokarst lakes. After lake drainage, highly productive plant communities on nutrient-rich sediments may develop, thus increasing the influencing greening trends of Arctic tundra [7]. Thermokarst features, such as thaw ponds of thermokarst lakes, are hotspots for methane emissions in warming lowland tundra [8].

In contrast to the northeastern European tundra, where both the climatic optima of the Atlantic and Subboreal of the Holocene, and, at present, permafrost has been thawing due to warming [9], in the tundra zone of Western Siberia, even the maximum warming 
occurred within the range of negative mean annual soil temperatures and, thus, did not lead to the permafrost retreat $[5,10]$. However, very-high-resolution (VHR) images showed various types of disturbances over permafrost areas' extensive networks of hydrocarbon exploration and infrastructure occurring in the Yamal Peninsula in the last several decades, stimulating the initiation of new thermokarst features [11,12]. The significant warming and seasonal variations of the hydrologic cycle, in particular, increased snow water equivalent acting in favor of deepening of the active layer; thus, an increasing intensification of the processes of thawing of underground ice wedges and destruction of soil-geocryological complexes of polygonal peatlands [13]. Peatlands are the most stable from the standpoint of the temperature state of permafrost [14], but the high amount of ice wedges in soilgeocryological complexes makes them very vulnerable to anthropogenic impacts [15]. Our earlier studies in the European Northeast with the use of high-frequency, groundpenetrating radar showed that the construction and operation of a road embankment with a hard cement-concrete coating crossing peat plateaus in the southern permafrost was limited, leading to the permafrost table retreating down to $8 \mathrm{~m}$, and the warming effect of the road construction affected the field $50 \mathrm{~m}$ wide [16].

Nowadays, there is increasing attention to the study of peat genesis and properties, since peat supports and affects bog ecosystems, which have a unique communities' structure and a high biodiversity level $[4,10,17,18]$. However, publications on the features of the permafrost peatlands' evolution are extremely insufficient [7,19-22] and spore-pollen spectra studies are limited $[4,23,24]$. Significant reserves of soil organic carbon are conserved as a peat. Therefore, the peat pool plays an important role in the biogeochemical carbon cycle and climate change processes [25]. Peat monoliths are archives of information on paleoenvironmental conditions [26].

The aim of the study was to characterize the evolution and current state of ancient peat plateaus (polygonal peatlands), at the southern limit of the continuous permafrost in Western Siberia, as well as to analyze their vulnerability to anthropogenic impact.

\section{Results}

\subsection{Landscape Settings and Plant Communities}

The studied peatland is a fissured, convex-polygonal, shrub-lichen on polygons, and dwarf-sphagnum bog in interpolygonal depressions, bounded on both sides by thermokarst lakes (Figure 1). The peatland has polygons $10-40 \mathrm{~m}$ in diameter. The polygons are in different development stages, and occupy from 80 to $90 \%$ and more of the total bog area. As a natural one, the polygonal peatland is almost flat from the surface. The excess of polygons in depressions, representing wide cracks, is no more than $0.5 \mathrm{~m}$. Polydominant shrub-lichen and shrub-ledum-lichen phytocenoses are widespread at the polygons. The portion of peat circles (bare peat patches) is insignificant, less than $1 \%$ of the peatland. The peat circles with a diameter of $0.5-2 \mathrm{~m}$ are developed mainly at the polygon edges. The polygons' surface is ombrotrophic, having typical but commonly sparse and depressed bog vegetation. Ledum palustre, Betula nana, and Rubus chamaemorus are dominant shrubs, less often with Oxycoccus microcarpus and Empetrum hermaphroditum, and occasionally are found Vaccinium vitis-idaea and V. uliginosum. The projective vegetation cover of each of these species varies from 5\% to $25 \%$. The ground layer is dominated by lichens, over $70 \%$. The most abundant and constant species are Cladonia rangiferina, C. arbuscula, C. stellaris, Flavocetraria nivalis, and F. islandica (total coverage up to $40 \%$ ). The portion of other lichens is much lower. The abundance of mosses does not exceed 30\%. Polytrichum strictum, Pleurozium schreberi, and Dicranum elongatum mostly grow in these communities. Sphagnum mosses (Sphagnum fuscum and S. compactum) are rare in occurrence. In the interpolygonal depressions, shrub-grass-sphagnum phytocenoses dominate. The grass-dwarf shrub layer is represented mainly by Betula nana and Eriophorum media, as well as by Rubus chamaemorus and Oxycoccus microcarpus, and, in the ground layer, Sphagnum fuscum and S. compactum. 


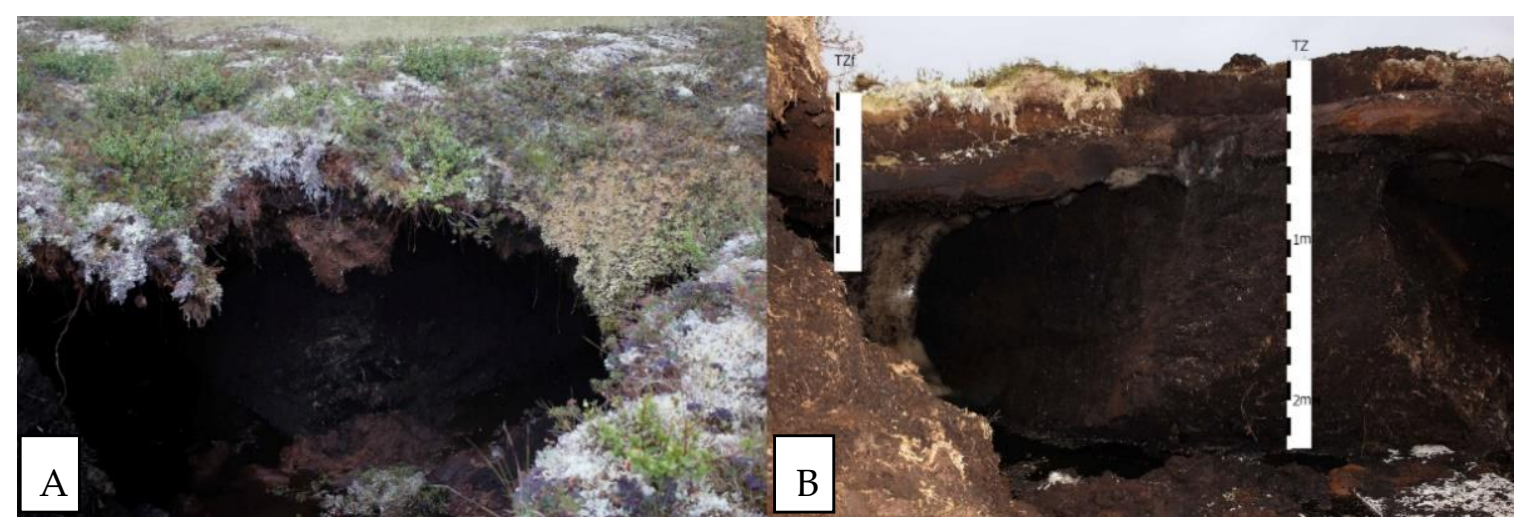

Figure 1. Vegetation cover (A) and TZ and TZf soils (B) developed in the peatland: Hemic Muusic Histosols (TZf) and Ombric Sapric Cryic Histosols (Hyperorganic) (TZ).

\subsection{The Current State of the Permafrost of the Polygonal Bogs}

Permafrost peatlands are typical bog geosystems in permafrost environments in Canada [27], Scandinavia [28], European Russia [19], and Siberia [4,5]. Permafrost initiation involves peatland surface upheaval that results in drying of the peat surface, which is often prone to abrasion and erosion processes [29]. Scandinavian palsa mires [30] on Eastern European peat plateaus [3] occur at the marginal zone of permafrost distribution. Therefore, they may react rapidly to small changes in climate conditions such as warming and increasing precipitation. However, even with this, the small active layer thickness is caused by seasonal variations in the heat conductivity of the surface peat, which protects the soil-geocryological complexes of permafrost peatlands from thawing [31]. In contrast to palsas, the Western Siberian Arctic peatlands occur in much more severe environmental conditions. Even a significant (by $10-15^{\circ} \mathrm{C}$ ) climate warming during the Holocene Atlantic optimum occurred on a vast area within the limits of negative temperatures and did not lead to the permafrost degradation. The climatic conditions of this epoch did not allow thawing of Arctic permafrost peatlands, reinforced with ice wedges. Ice wedges did not thaw from the surface even in the southernmost part of the Yamal Peninsula $\left(67^{\circ} \mathrm{N}\right)[5]$.

As a result of the construction and operation of a bulk road with a cement-concrete coating, the peatland hydrological regime changed rapidly. The processes of thermal corrosion and thermokarst resulted from ice wedges thawing in the interpolygonal depressions. In this case, the polygon edges collapsed, and residual peat mounds developed. The height of such polygonal "mounds" relative to the bottom of the interpolygonal depressions might exceed $3.5 \mathrm{~m}$. Polygonal peatlands were transformed into peat plateau complexes, which clearly proves the erosion hypothesis of their origin, formulated by N.I. Pyavchenko $[32,33]$. Polygons located close to the road have a slightly different vegetation cover and structure of communities. Shrubs are taller and thicker. Betula nana and Salix phylicifolia grow on the slopes of the destroyed polygons. In the vegetation cover, the role of Eriophorum media increased significantly. The ground layer is composed mainly by mosses (Sanionia uncinata, Pleurozium schreberi, Polytrichum strictum). Deep cracks and depressions are waterlogged or filled with peat, occasionally covered by sedge communities (Carex limosa or C. paupercula, less often Carex chordorrhiza and C. rotundata).

\subsection{Soils and Structure of the Peat Strata of the Polygonal Peatland}

According to the International Soil Reference Base [34], the soils of the polygons are classified as Ombric Sapric Cryis Histosols (Hyperorganic), the characteristic diagnostic features of which are the presence of well-decomposed organogenic material (peat), predominantly of atmospheric nutrition with a thickness of more than $2 \mathrm{~m}$ and the occurrence of a permafrost table within $1 \mathrm{~m}$. Hemic Muusic Histosols have moderately decomposed peat located directly above the polygonal-veined ice, filling the interpolygonal cracks. Om- 
bric Sapric Cryic Histosols (Hyperorganic Turbic) are formed on peat circles (bare patches). In contrast to the polygon, the soils of the peat circles are cryoturbated in the upper peat horizon with the processes of exfoliation and structuring of peat.

Below are descriptions of peat soils in polygons and interpolygonal cracks in the study area, as well as an analysis of the plant macrofossils and spore-pollen composition of the soil horizons.

The TZ profile is located at the polygon edge with a recently thawed ice wedge (Figure 1; Appendix A). The height of the polygons relative to the bottom of the thawed crack exceeds $3.5 \mathrm{~m}$. The crack, starting from a depth of $2.3 \mathrm{~m}$, is filled with water and peat that has fallen from the edges of the polygon. The vegetation cover is shrub-lichen and consists of Betula nana, Ledum palustre, Rubus chamaemorus, lichens, and hypnum mosses. Peat circles occupy up to $10 \%$ of the site. The active layer depth on 15 August 2017 was $35 \mathrm{~cm}$.

The studied polygonal peatland is composed mainly of Ledum-hypnum, Ledumsphagnum, and grass-sphagnum peat with an admixture of dwarf shrubs (Figure 1). At the initial stage, on the site of the polygon, there was a grass- and sedge-moss eutrophic community dominated by Equisetum sp., Carex limosa, C. rotundata, and Menyanthes trifoliate. Periodically, the moisture conditions changed and hypnum mosses replaced sphagnum for a long time. Only the upper $20 \mathrm{~cm}$ of peat strata are mainly composed of mesotrophic dwarf shrubs, which are also common for present-day vegetation (Salix sp., Betula nana and species of Ericaceae).

The stratigraphic description of the soil-geocryological complex TZ indicates six stages of its genesis (Figure 2):

VI—oligotrophic: Ericales (Ledum palustre + Vaccinium uliginosum) - Dicranum sp. + Polytrichum sp. V-eutrophic: Menyanthes trifoliata - Sphagnum warnstorfii + S. centrale, IV—eutrophic: Equisetum + Menyanthes trifoliata - Sphagnum warnstorfii, III-eutrophic: Equisetum + Menyanthes trifoliata - Sphagnum warnstorfii + Calliergon sp., II-eutrophic: Equisetum + Menyanthes trifoliata - Sphagnum warnstorfii, I- eutrophic: Equisetum + Menyanthes trifoliata + Carex limosa - Sphagnum warnstorfii + Meesia

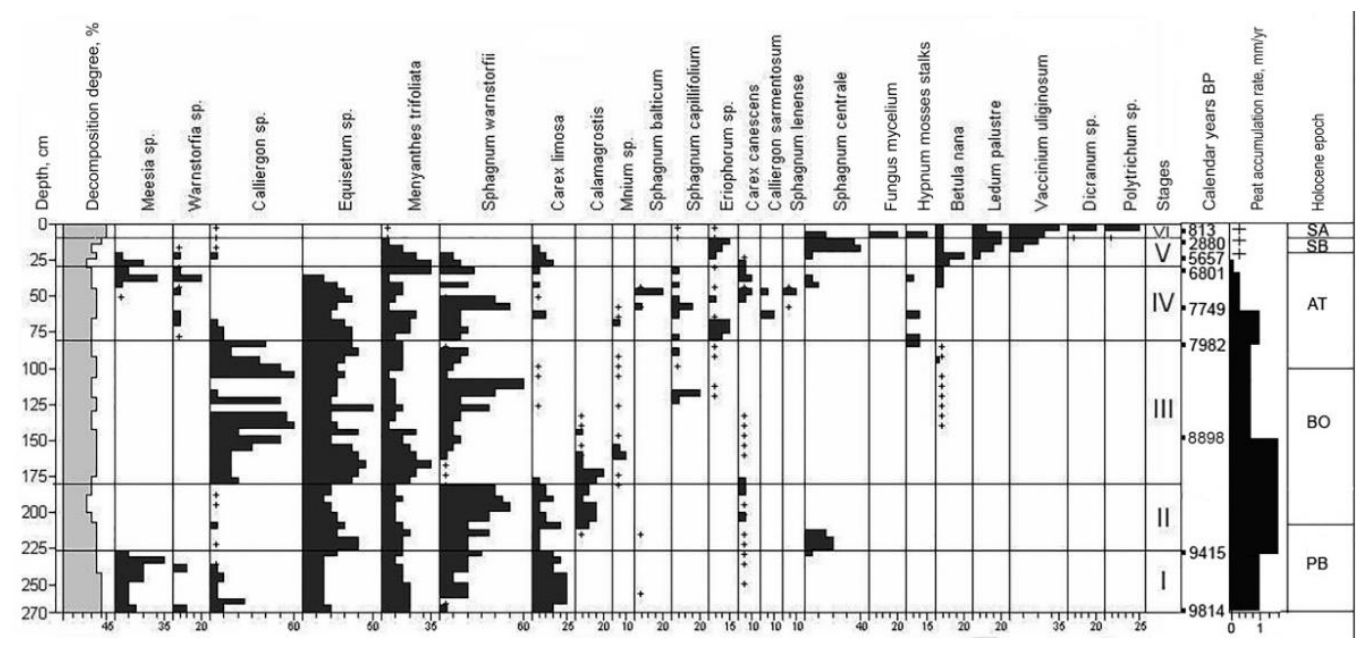

Figure 2. Plant macrofossil composition of TZ. $+-0.5-2 \%$ of the sum of all species encountered. In the column "calendar age, years", the dates 813, 2880, 8898, and 9415 are cited from the PhD thesis of Ya.V. Tikhonravova (laboratory numbers IMKES-14C1488, -14C1487, -14C1473, -14C1477, respectively) [35].

The TZf profile is located at the interpolygonal cracks near the TZ profile (Figure 1; Appendix A). The vegetation cover is shrub-lichen and consists of Betula nana, Rubus chamaemorus, Vaccinium oxycoccos, Eriophorum vaginatum, and sphagnum mosses. The active layer thickness on 15 August 2017 was $35 \mathrm{~cm}$. 
The studied interpolygonal depression is composed mainly of sphagnum and herbaceous peats (Figure 3). At the initial stage, on the site of the depression, there was an herbaceous and grass-sedge eutrophic community dominated by Equisetum sp., Eriophorum sp., Menyanthes trifoliata, Scheuchzeria palustris, Carex limosa, and C. chordorrhiza. Then, obviously, sharply drier and colder conditions set in, and herbaceous phytocenoses first were replaced by oligotrophic Sphagnum (Sphagnum lenense), later by cushy-sphagnum communities (Sphagnum lenense, S. balticum, Eriophorum sp.) and, finally, by mesotrophic shrub-sphagnum plant communities (Sphagnum balticum, Ericales).

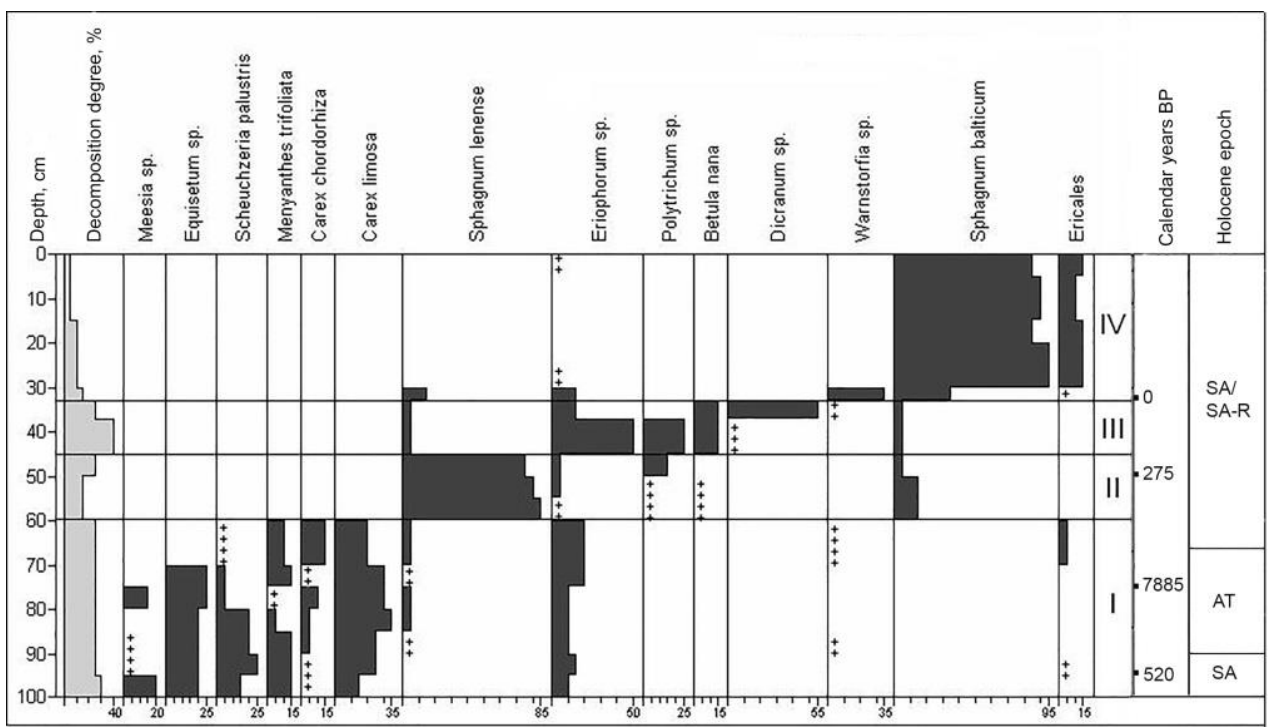

Figure 3. Plant macrofossil composition of TZf. $+-0.5-2 \%$ of the sum of all species encountered.

The stratigraphic description of the soil-geocryological complex TZf indicates four stages of its genesis (Figure 3):

IV—mesotrophic: Ericales - Sphagnum balticum,

III-transitional: Eriophorum sp. - Polytrichum sp. + Dicranum sp.,

II-oligotrophic: Eriophorum sp. - Sphagnum lenense,

I—eutrophic: Equisetum + Menyanthes trifoliate + Scheuchzeria palustris + Carex limosa.

\subsection{Spore-Pollen Zones of Peat Strata}

Palynological analysis of 48 samples collected from the TZ profile indicated the presence of pollen and spores of a good preservation degree. There were also mineral, plant, and post-pyrogenic carbonaceous remains, with sponge spicules. Seven spore-pollen zones were identified totally (Figure 4).

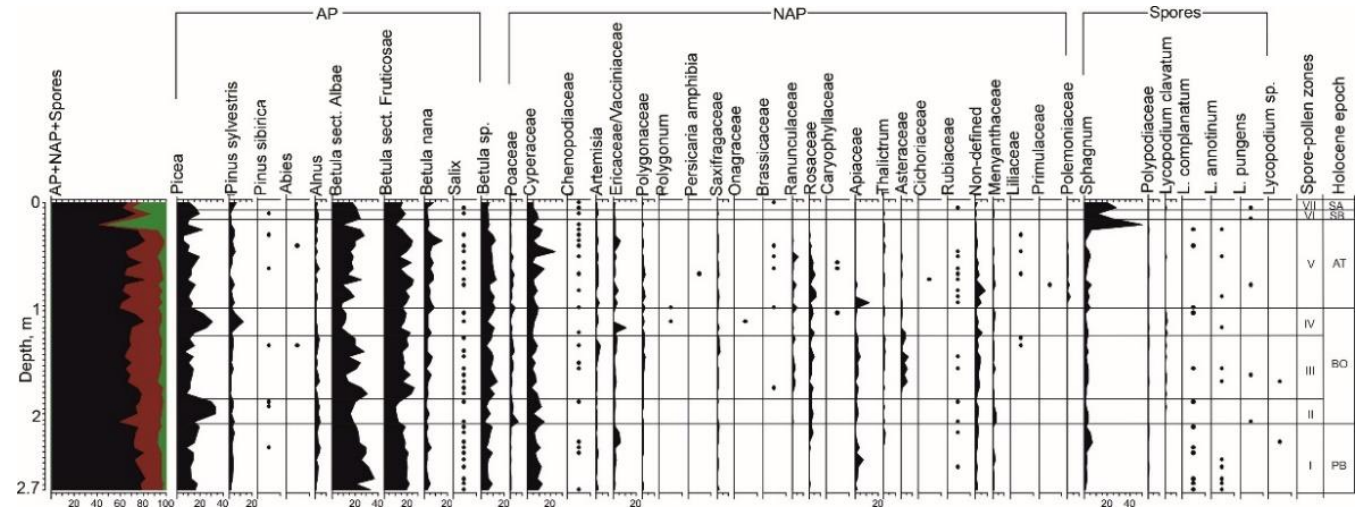

Figure 4. Spore-pollen diagram of TZ. •- $0.5-2 \%$ of the sum of all species encountered. 
Spore-pollen zone I (11 samples at 2.7-2.1 m; 9814-9350 cal. yr. BP; Appendix B: Figure A1). The total composition was dominated by pollen of trees and shrubs (60-83\%). Herbaceous plants were found to be more than $35 \%$ and spores were $2-7 \%$. Among trees, small-leaved species constituted the main share, e.g., species of genus Betula L.: Betula sect. Albae (over 36\%), Betula sect. Fruticosae (over 22\%), Betula nana (up to 6.6\%), and Betula sp. (9\%). The group of conifers was represented by Picea sp. (up to 19\%) and Pinus sylvestris (up to $4.8 \%$ ). Pollen of herbaceous plants was dominated by Cyperaceae (up to 14.7\%). Vacciniaceae-Ericaceae, Poaceae, Artemisia sp., and Chenopodiaceae were also found. Grass was represented by Apiaceae (up to 7\%), Polygonaceae, Rosaceae, Ranunculaceae, Rubiaceae, and Saxifragaceae. The hydrophilous Menyanthaceae was noted (up to $2 \%$ ). Spore plants were represented by Sphagnum sp. (up to $4 \%$ ), ferns of Polypodiaceae, and Lycopodium sp.

Spore-pollen zone II (three samples at 2.1-1.87 m; 9350-9250 cal. yr. BP). The total composition was dominated by pollen of trees and shrubs (about $78 \%$ ). The share of pollen of herbaceous plants was more than $23 \%$. Spores were almost $4 \%$. Among trees and shrubs, species of the genus Betula L. predominated, but their proportion was decreasing: Betula sect. Albae (up to 19.6\%), Betula sect. Fruticosae (13\%), Betula nana (up to $4.4 \%$ ), and Betula sp. (up to $7.5 \%$ ). In the group of conifers, the share of Picea sp. was up to $33.6 \%$. Pinus sylvestris, P. sibirica, Alnus sp., and Salix sp. were singles. The pollen composition of herbaceous plants was still dominated by Cyperaceae (almost 12\%). Poaceae, VacciniaceaeEricaceae, Artemisia sp., and Chenopodiaceae were also found. Among grass, the species of Ranunculaceae, Polygonaceae, Rosaceae, Caryophyllaceae, Apiaceae, and the hydrophilous Menyanthaceae (2.6\%) were noted. Few spore plants were found, e.g., Polypodiaceae, Sphagnum sp., and Lycopodium sp.

Spore-pollen zone III (10 samples at $1.87-1.3 \mathrm{~m}$; $9250-8898$ cal. yr. BP). The total composition of the spectra was still dominated by the pollen of trees and shrubs (up to $80 \%$ ), while herbaceous pollen is about $32 \%$. The amount of spores was up to $6.7 \%$. Betula sect was dominant, e.g., Albae (up to 30\%), Fruticosae (almost 26\%), and B. nana (6\%). In the group of conifers, the abundance of Picea sp. decreased significantly (up to $15 \%$ ), while Pinus sylvestris and P. sibirica were single. The pollen composition of herbaceous plants was still dominated by Cyperaceae (up to $8 \%$ ), but its amount was decreasing. Poaceae, Vacciniaceae-Ericaceae, Artemisia sp., and Chenopodiaceae were found. Grass was represented by Asteraceae (up to 6.6\%), Ranunculaceae, Polygonaceae, Rosaceae, Apiaceae, and Menyanthaceae. Spore plants were dominated by Sphagnum sp. (3.4\%). Polypodiaceae and Lycopodium sp. are rare.

Spore-pollen zone IV (five samples at 1.3-1.02 m; 8898-8000 cal. yr. BP). In the total composition of the spectra, the pollen of trees and shrubs still prevailed (up to $82 \%$ ), while herbaceous pollen was about $25 \%$ and spores were up to $5 \%$. Despite the predominance of Betula L., the share of conifers significantly increased, e.g., Picea sp. (up to 31\%) and Pinus sylvestris (up to $13 \%$ ). The share of pollen of Betula sect. Fruticosae was up to $23 \%$, while B. sect. Albae and B. nana decreased to almost $13 \%$ and to $6 \%$ respectively. Alnus sp. and Salix sp. were found. Among herbaceous plants, Vacciniaceae-Ericaceae was predominant $(10.6 \%)$ but Cyperaceae decreased to $8 \%$. Poaceae, Artemisia sp., and Chenopodiaceae were noted. Grass was represented by Apiaceae, Rosaceae, Ranunculaceae, Polygonaceae, Onagraceae, and Saxifragaceae. Among spore plants, Polypodiaceae, Sphagnum sp., and Lycopodium sp. were noted.

Spore-pollen zone V ( 15 samples at $1.02-0.2 \mathrm{~m} ; 8000-4800$ cal. yr. BP). The total composition of the spectra was dominated by pollen of trees and shrubs (about $80 \%$ ). Herbaceous pollen was up to $35.6 \%$, while spore plants were almost $6 \%$. Among trees, the main species' composition was preserved. The dominant groups were Betula sect. Albae (25.5\%), B. sect. Fruticosae (25.8\%), and Picea sp. (almost 16\%). Pinus sylvestris, Betula nana (up to 8\%), Alnus sp., and Salix sp. were found in small quantities. The composition of herbaceous pollen became more diverse. Cyperaceae reached 14.5\%. Vacciniaceae-Ericaceae, Poaceae, xerophytes: Artemisia sp., and Chenopodiaceae were found. Among mesophilic grass, 
Apiaceae (12.6\%), Rosaceae (6\%), Ranunculaceae (almost 5\%), Polygonaceae, Primulaceae, Polemoniaceae, Brassicaceae, and Menyanthaceae were noted. Spore plants were rare, e.g., Sphagnum sp. (up to 5.5\%), Lycopodium complanatum, L. annotinum, and L. pungens.

Spore-pollen zone VI (two samples at 0.2-0.1 m; 4800-2500 cal. yr. BP). The total composition was dominated by pollen of trees and shrubs (almost $82 \%$ ), while herbaceous plants ranged from $8 \%$ to $30 \%$ and the share of spores varied from single values to $50 \%$. Among trees, small-leaved species were still the most widespread, e.g., species of the genus Betula L.: B. sect. Albae (up to 28\%), B. sect. Fruticosae (almost 25\%), and B. nana (increased to $16 \%$ ). Picea sp. varied from $5 \%$ to almost $22 \%$. Pinus sylvestris was above 5\%, while P. sibirica and P. Abies sp. were singles. Alnus sp. and Salix sp. were noted. The composition of herbaceous plants, in general, throughout the entire zone was preserved. Sedges still dominated (up to $24 \%$ ), and their participation was noticeably increasing, e.g., Vacciniaceae-Ericaceae (about 6\%). Poaceae, Artemisia sp., and Chenopodiaceae were noted. Grasses were represented by Ranunculaceae, Rosaceae, Polygonaceae, and Apiace. Among spore plants, Sphagnum sp. dominated, reaching almost 50\% in one sample of all encountered forms. Spores of Polypodiaceae and Lycopodium sp. were noted.

Spore-pollen zone VII (two samples at 0.1-0 m; 2500 cal. yr. BP-Present). The total composition of the spectra was dominated by pollen of trees and shrubs (76\%). Herbaceous pollen was almost $17 \%$. Among trees, Betula sect. Albae still prevailed (up to 25\%), while B. sect. Fruticosae was almost $19 \%$ and B. nana decreased to $2-8 \%$. Picea sp. was more than 21\%. Pinus sylvestris, P. sibirica, Alnus sp., and Salix sp. were found. Herbaceous plants contained pollen from Cyperaceae (up to 12.6\%), Vacciniaceae-Ericaceae, Poaceae, and Artemisia sp. The participation of mesophilic grass decreased. Among spore plants, sphagnum mosses dominated, reaching almost 50\% in one sample of all encountered forms. Spores of Polypodiaceae, Lycopodium clavatum, L. complanatum, L. annotinum, and L. pungens were noted.

Palynological analysis of 19 samples collected from the interpolygonal depression (TZf section) indicated the presence of pollen and spores of a good degree of preservation. There were also mineral, plant, and post-pyrogenic carbonaceous remains, with sponge spicules. Two spore-pollen zones were identified (Figure 5).

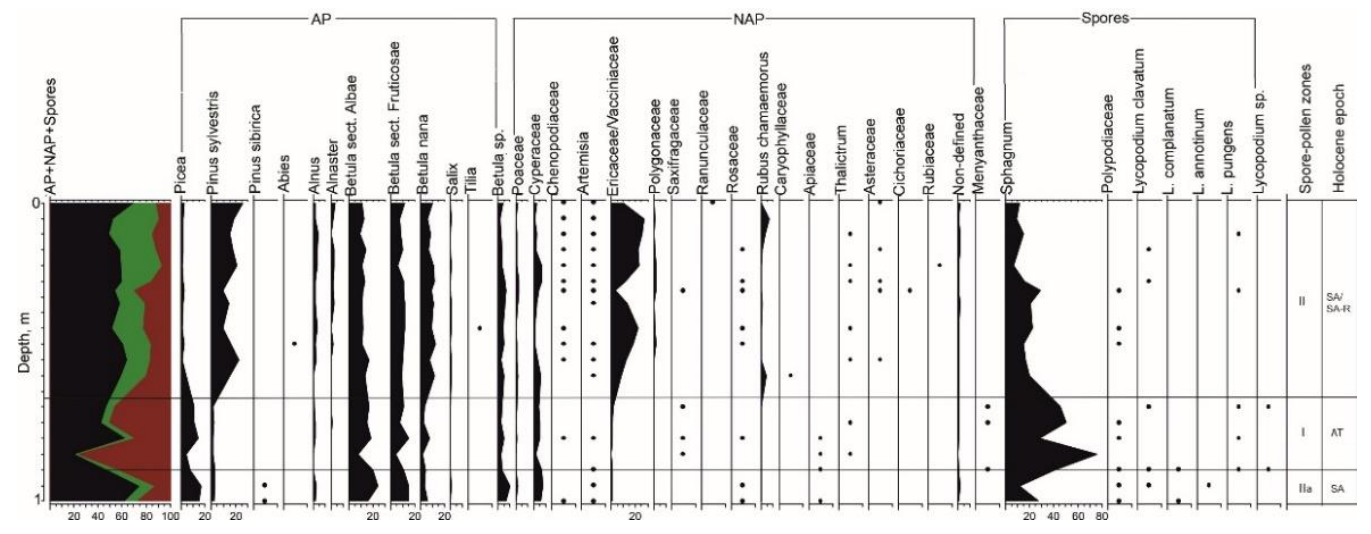

Figure 5. Spore-pollen diagram of TZf. •- $0.5-2 \%$ of the sum of all species encountered.

Spore-pollen zone IIa (two samples at 1.0-0.9 m). The total composition of the spectra was dominated by the pollen of trees and shrubs (about 70\%), but the share of herbaceous plants was insignificant (up to $9 \%$ ). Spores varied from $12 \%$ to $40 \%$. Among trees, the genus Betula L. predominated, e.g., B. sect. Albae (17.5 to 25\%), B. sect. Fruticosae (10-15\%), and $B$. nana (5-7\%). The group of conifers was represented by Picea sp. (up to 16.7\%), Pinus sylvestris (up to 3\%), and P. sibirica. Alnus sp., Salix sp., and Alnus alnobetula Subsp. fruticosa were singles. Among the encountered herbaceous plants, only Cyperaceae was noticeable (up to 6-9\%). Sphagnum sp. dominated among spore plants (up to 40\%). Polypodiaceae, Lycopodium clavatum, and L. annotinum were rare. 
Spore-pollen zone I (4 samples at 0.9-0.7 m). The total composition of the spectra was mainly dominated by the pollen of trees and shrubs (above $75 \%$ ). Spore plants dominated in two samples (50.6\% and almost $76 \%$ ). Herbs made up $2-12 \%$. In the group trees, species of the genus Betula L. generally prevailed, e.g., B. sect. Albae (almost $24 \%$ ), B. sect. Fruticosae (up to $15 \%$ ), and B. nana (up to $7 \%$ ). The pollen of herbaceous plants was rare, e.g., the predominant Cyperaceae was only $7.4 \%$, while VacciniaceaeEricaceae, Poaceae, Artemisia sp., and Chenopodiaceae were singles. Apiaceae, Rosaceae, Polygonaceae, Ranunculaceae, and Menyanthaceae were found among mesophilic grass. Spore plants were dominated by Sphagnum sp. (up to 76\%). Polypodiaceae, Lycopodium clavatum, L. complanatum, L. annotinum, and L. pungens were rare.

Spore-pollen zone II (13 samples at 0.7-0 m). In the total composition of the spectra, the share of pollen of trees and shrubs dominated and reached almost $71 \%$. Herbaceous plants varied from $16 \%$ to $38 \%$, spores ranged from $6-30 \%$. Small-leaved species of the genus Betula L. still predominated, e.g., B. sect. Albae (9-13\%), B. sect. Fruticosae (up to $12 \%)$, and B. nana $(12.5 \%)$. Picea sp. strongly decreased from $4 \%$ to single values, while the share of Pinus sylvestris increased to $26 \%$. Alnaster sp. (up to 3\%), Abies sp., Alnus sp., and Salix sp. were found. The composition of herbaceous plants was preserved in general throughout the entire zone. Vacciniaceae-Ericaceae (about 27\%) noticeably increased, while Cyperaceae (6\%) and Rubus chamaemorus (up to 7\% in some samples) were found in fairly large numbers. Among grass, Ranunculaceae, Rosaceae, Polygonaceae, and Asteraceae were noted. Among spores, Sphagnum sp. predominance was significantly reduced to 6-29\%. Polypodiaceae and Lycopodium sp. were also found.

\subsection{Ground-Penetrating Radar Survey}

On the radarogram of the GPR profile 1 in the PK 0-2 segment, the in-phase axis was clearly traced, reflecting the changes of the permafrost table surface (Figure 6). If, under the conditions of an undisturbed polygonal peatland, the permafrost table depth varies in the range of $0.4-0.5 \mathrm{~m}$ (markers 2-3), while approaching the road embankment, the permafrost table retreats to a depth of $1 \mathrm{~m}$ and below (markers $0-1$ ). Thus, the active layer thickness increases under the road embankment warming effect.

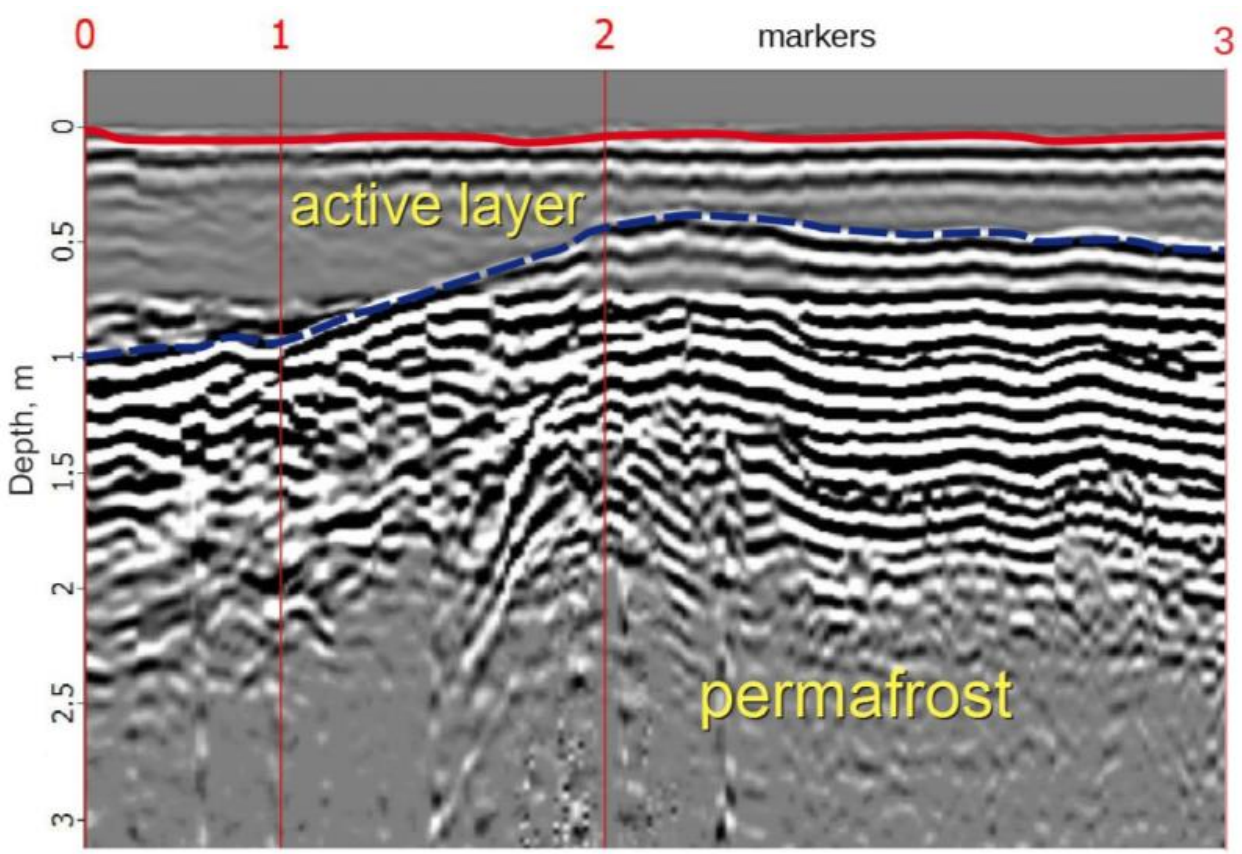

Figure 6. GPR profile 1 (roadside- - undisturbed polygonal peatland) according to the data obtained with a $300-\mathrm{MHz}$ antenna. 
In interpolygonal depressions, the permafrost table is $10-20 \mathrm{~cm}$ lower relative to the main surface under the native conditions of undisturbed peatland (Figure 7, PK 3). The depressions are distinguished by a stronger watering of the soil profile, which contributes to increased thermal conductivity and, accordingly, a greater depth of seasonal thaw.

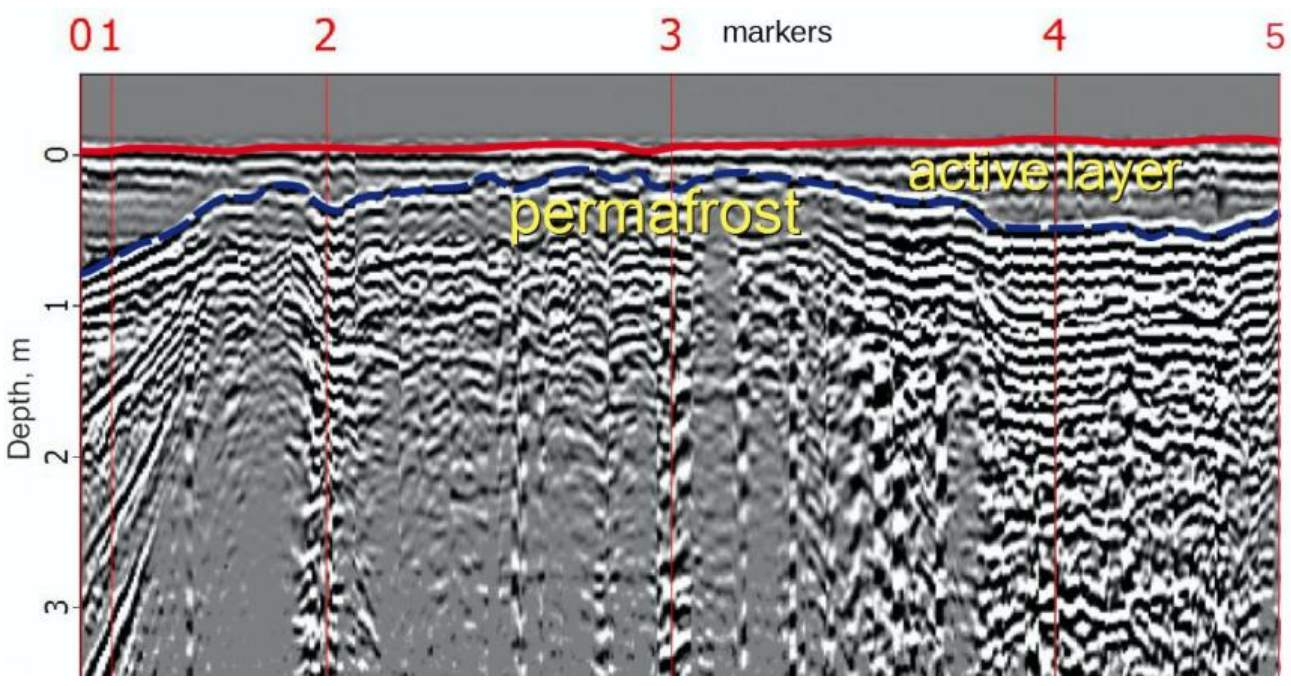

Figure 7. GPR profile 2 (thawing crack-polygonal peatland-crack) according to the data obtained with a $300-\mathrm{MHz}$ antenna.

\section{Discussion}

Studies on the Western Siberia region show that the active process of peat accumulation started in the Preboreal stage. Bogs were formed as a result of the end of the Sartan glaciation and the beginning of climate warming, but their development proceeded in local sites in well-pronounced microdepressions [10]. As with the oldest and largest peat deposits in the Eastern European forest-tundra and tundra [21,36], the studied peatland TZ began to develop as a result of the paludification of mixed birch and coniferous woodlands earlier than $9814 \mathrm{cal}$. yr. BP at a rate of $1 \mathrm{~mm}$ per year during the Preboreal (PB) (10,300-9000 cal. yr. BP) (Figure 3). No other ancient dates were obtained for a thick peatland (peat deposit exceeds $5 \mathrm{~m}$ ) developed on the high sea terraces of the Gydan Peninsula, 9940 cal. yr. BP at a rate of $0.7 \mathrm{~mm} /$ year [4]. The severe continental climatic conditions of the Late Dryas changed to a milder and humid climate [37], and the bog system development began with the overgrowing and peat formation of lakes of various genesis, which were mostly thermokarst with submerged taliks. During the second half of the Preboreal (PB, zone I, 9580-9350 cal. yr. BP), birch-spruce woodlands predominated in the study area. Groups of shrub and dwarf birches played a great role, while pine was an admixture. Bog-tundra plant communities are widespread.

At the beginning of the Boreal (BO-1, zones II, IV), the climate became warmer and more humid. There was a gradual increase in the role of spruce and the participation of $B e-$ tula sect. Albae had more than halved. The presence of dwarf and shrub birches was greatly reduced. In open sites, bog-herbaceous communities were widespread, with a significant increase of sphagnum mosses. The rate of peat accumulation reached $1.5 \mathrm{~mm} / \mathrm{yr}$., up to the end of the Boreal climatic optimum. However, after 8898 cal. yr. BP (BO-2, zone III), there was a reduction in forest vegetation and an increase in groups of dwarf and shrub birches, alder, and willow. At the same time, the rate of peat accumulation was reduced by more than two times, to $0.7 \mathrm{~mm}$ /year.

During the entire Atlantic (AT, zone V) (8000-4800 cal. yr. BP), spruce-birch forests predominated in the study area. The forest area periodically increased and then decreased depending on climate fluctuations. In open sites, fen-herbaceous plant communities were developed. If, at the beginning of the Atlantic period, the peat accumulation rate reached $1 \mathrm{~mm} / \mathrm{yr}$., then, from 7749 cal. yr. BP, it was about $0.26 \mathrm{~mm} / \mathrm{yr}$., and from 6801 to $5657 \mathrm{cal}$. 
yr. BP it was only $0.13 \mathrm{~mm} /$ year, after which it almost stopped. In the Subboreal (SB, zone VI) (4800-2500 cal. yr. BP), there was a decrease in taiga and an increase in areas occupied by dwarf thickets of Betula sect. Fruticosae and B. nana. Herbaceous associations of sedges and mesophilic grasses were developed in fens.

In the Subatlantic (SA, zone VII) (2500 cal. yr. BP-present), spruce-birch woodlands are widespread, which alternates with extensive fens. The data of the plant macrofossil composition indicate the transition of the eutrophic stage of the bog transformation into the oligotrophic stage, accompanied by a change in the species' composition of paleocommunities (the replacement of fen grass-moss peats with dwarf shrub-hypnum peats). The possible mechanisms for that could not be explained by climatic changes but was a result of restorative succession after vegetation cover disturbances under local factors (fires, since carbonaceous residues are recorded, and/or changes in hydrological conditions due to permafrost heaving) in the surrounding area.

Thus, paleoreconstruction shows that intensive peat accumulation began as early as the Preboreal, when the temperature and moisture content were even lower than contemporary ones, and the slowing to almost complete cessation of peat accumulation occurred already in the middle of the Atlantic period, when the maximum climatic optimum still went on. For such arctic peatlands, a fairly clear temporal limitation of the period of their most active vertical growth was noted, from 9000 to 6000 years ago, with a rate reaching $1.5-4.4 \mathrm{~mm}$ /year. These environmental conditions (due to a unique combination of temperature and moisture) had been no longer repeated either in the second half of the Atlantic period or later [5]. The irregularity of the peat accumulation rates is explained both by active soil heave [38] and following peat cryoturbations, as well as by the predominance of texture-forming, congelation, and wedge-shaped ice in the peat soil, when the mass fraction of biogenic material (peat) is commonly less than $10 \%$ of the total mass [5]. In the interpolygonal depression (site TZf, Figure 5), an inversion of two radiocarbon dates was observed: The median age of peat at a depth of $70-75 \mathrm{~cm}$ is $7885 \mathrm{cal}$. yr. BP, and at a depth of $90-95 \mathrm{~cm}-520$ cal. yr. BP. Obviously, this inversion is explained by the result of the peat turbation due to the formation and growth of an underground ice wedge. Thus, in the studied site, a space of 60-65 cm was filled with a horizontal ice vein, expanded to $20 \mathrm{~cm}$ on the left wall, and turned into a large block of ice wedges, over $3 \mathrm{~m}$.

In contrast to the tundra and forest-tundra of the European Northeast, where peat accumulated in non-permafrost bogs covered with woody plants, sedges, and mosses and permafrost appeared only at the beginning of the Subboreal (4600-4300 cal. yr. BP), after which, during warming, the degradation of permafrost repeatedly occurred, in the West Siberian tundra, even the maximum warming of the Atlantic optimum climate occurred within negative temperatures and did not lead to a significant degradation of the permafrost table. Model calculations show that by 2050 yr. in Western Siberia, due to global warming, the air temperature may rise by $0.9-1.5{ }^{\circ} \mathrm{C}$ and the humidity will increase by $12-39 \%$ [39]. Similar climate changes occurred during the Atlantic (about 8000 cal. yr. BP), and in such a climate the peatlands absorbed significant amounts of atmospheric carbon, with peat accumulation rates reaching $0.5 \mathrm{~mm} / \mathrm{yr}$. [40]. Therefore, under natural conditions, it can be assumed that the soil-geocryological complexes of studied and other Arctic peatlands will remain a stable carbon sink. It is believed that the West Siberian peatlands in the 21st century will not only remain a carbon sink, but will also increase its absorption [41]; however, the methane emission will obviously also increase [42]. Taking into account the higher Global Warming Potential of $\mathrm{CH}_{4}$ compared to $\mathrm{CO}_{2}$ (28-34 times) [43], increased methane emissions can significantly affect the overall impact of thawing permafrost, the degradation of arctic peatlands, and climate change.

Under the present-day climate warming, the vegetation cover of polygonal peatlands and peat plateaus protects the permafrost from thaw. When the surface of polygons and peat plateaus dries up, moss ground layer is replaced by lichens and peat circles are formed. However, dry peat provides thermal insulation, preventing further permafrost thawing. Such peatlands might collapse due to wind abrasion and thermal erosion, but thermokarst 
processes are uncommon there. The thawing of peat plateaus and polygonal peatlands occurs in case they are destroyed or under hindered surface runoff, when lake and fen formation occur. The main indicator of bog stability is the average long-term ground water level, and for permafrost peatlands, the thickness of the active layer is also equal to the averaged long-term depth of seasonal thawing of peat deposits [44]. Since the water levels in the bogs are close to the soil surface, any anthropogenic linear objects crossing them would change the bog runoff. Therefore, the construction of the road favored the flooding of the studied peatland, which led to a change in the hydrothermal regime and vegetation cover and an increase in the temperature of the upper permafrost as well as soilgeocryological complex degradation. Thus, technogenic impacts exceeded the potential stability of the studied peatland as a bog system, and, therefore, irreversible destruction processes may occur.

The analysis by ground-penetrating radar studies showed that the zone of the warming effect of the road as a result of changes in the hydrological regime of the investigated peatland already exceeds $50 \mathrm{~m}$. The most significant retreat of the permafrost table (up to $2-3 \mathrm{~m}$ ) was observed directly at the bottom of the slope of the road embankment, composed of loose sandy and sandy-loamy soils. The main reasons for the subsidence of the permafrost table are the transformation of the natural conditions serving the polygonal peatland ecosystem functioning. In roadside depressions, favorable conditions are created for waterlogging, the growth of tall shrubs, and snow accumulation as well [16]. The combination of these factors activates the thermokarst processes [45], resulting in a significant permafrost table retreat in the sites under road impact.

In natural regional ecosystems, the permafrost subsidence is less pronounced, in comparison with the zone of discontinuous permafrost in the European North. This is due to the greater stability of low-temperature, continuous permafrost in the North of Western Siberia. According to the classification scheme [46], the studied permafrost is classified as climate-conditioned, ecosystem-protected. In the case of ecosystem disturbances, permafrost in soil-geocryological complexes partially thaws, but repeated permafrost aggradation is also possible under favorable environmental conditions.

In this regard, it is necessary to pay attention to the protection and preservation of permafrost peatlands and to apply the concept of ecosystem services for the peatland use in the construction of infrastructure facilities. When designing and constructing the linear objects, it is required to arrange sufficient culverts to maintain the natural level regime of bog waters. Measures to prevent or reduce negative consequences on linear structures are the drawing up of grid lines of bog water runoff, determination of locations, and calculation of the size of culverts [44].

\section{Materials and Methods}

\subsection{Study Site}

The study area is located in the northeast of the Pur-Taz interfluve, $5 \mathrm{~km}$ west of the Gaz-Sale Settlement of the Tazovsky District of the Yamalo-Nenets Autonomous Okrug (Figure 8). This is an area of the subarctic southern tundra [47]. The climate of the region is cold-temperate with a moderate mean annual precipitation $(517 \mathrm{~mm})$ with long cold winters and relatively short, cool summers. The mean temperature of the coldest month of January is $-25.7^{\circ} \mathrm{C}$, while July is $+14.5^{\circ} \mathrm{C} ; 244 \mathrm{~mm}$ of precipitation falls in the summer time and September, while a stable snow cover forms in the first week of October and thaws only at the end of May-early June [48]. The averaged height of the snow cover is about $80 \mathrm{~cm}$; however, frequent snowstorms (on average 54 snowstorms per a year) contribute to intensive snow transport, on average $378 \mathrm{~m}^{3} /$ linear meter [49]. 


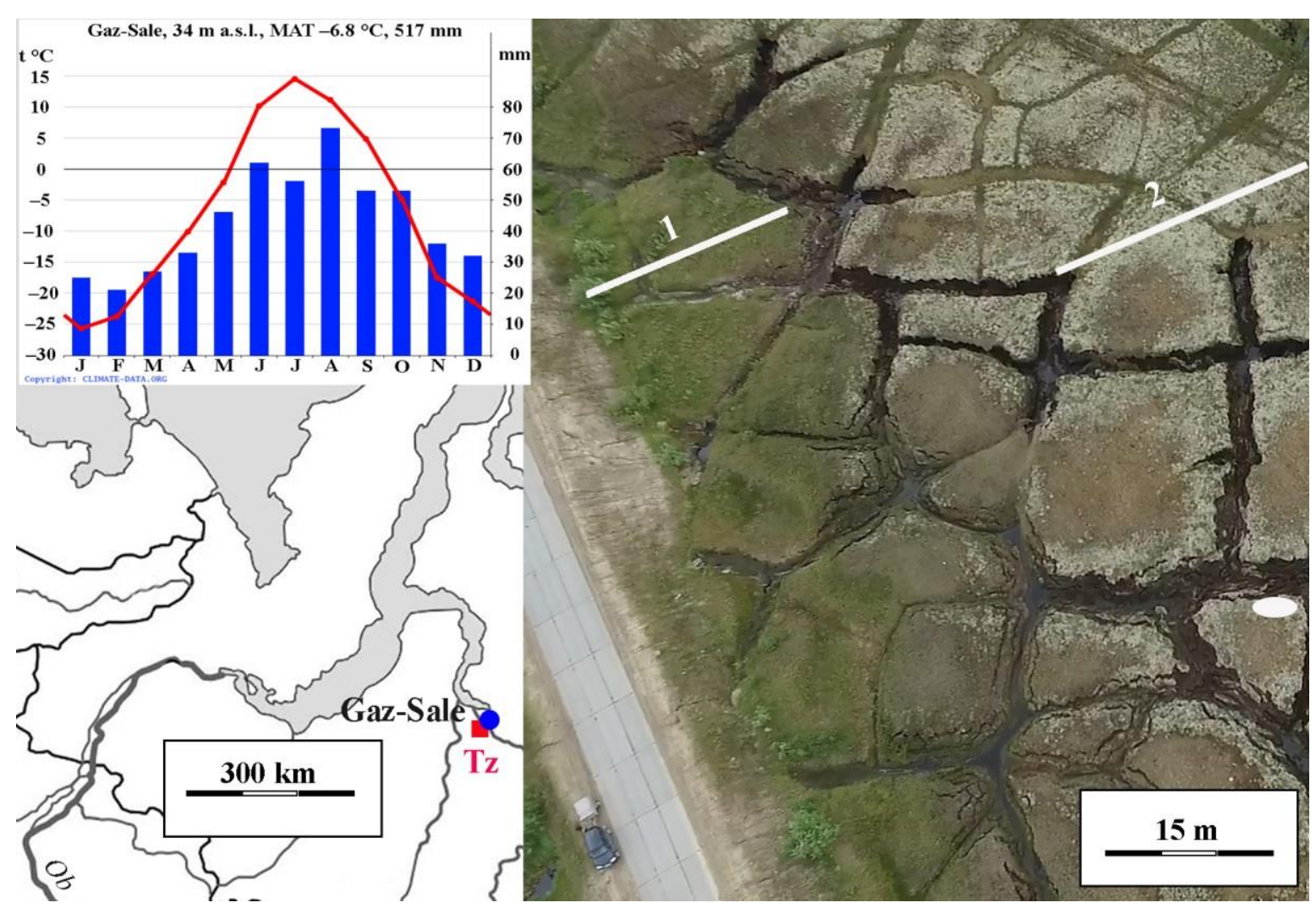

Figure 8. Location of the study area. Monthly temperatures and precipitation amounts based on the climatic database https:/ / ru.climate-data.org/ (accessed on 18 October 2021) [48]. White lines indicate GPR profiles 1 and 2, and the white oval is the study site. Area survey was made from Phantom IV drone by E. Istigichev.

The study area is located in a subzone of predominantly continuous permafrost with a thickness from 400-450 to 250-300 m at the latitude of the Arctic Circle. Taliks are found only under the channels of large rivers and deep lakes. The upper permafrost has quite low temperatures (from -3 to $-7^{\circ} \mathrm{C}$ ) and a significant distribution of syngenetic, ice-enriched (up to $40-60 \%$ ) sediments, often in the form of thick ice-soil wedges [50]. Weak relief dissection and the permafrost occurrence result in the waterlogging. Ice wedges, flat peat plateaus, and polygonal peatlands are rather common for the region. Thereby, thermokarst shallow streams and depressions with small and large ponds arose from the thawing of ice wedges and were widely developed. Aeolian and abrasion processes intensively affect steep slopes and river and lake banks [51].

The study site is a polygonal peatland located in the III lacustrine-alluvial plain in the northeast of the Pur-Taz Interfluve and crossed by the Tazovsky-Gaz-Sale bulk road with a concrete pavement. This road was built in 2006 and, despite the presence of culverts, greatly changed the hydrological regime of the bog system under consideration, which led to intensive permafrost thaw, in particular in interpolygonal ice wedges and veins. Previous studies in 2016-2017 also revealed sharp changes in the topography of the peatland under study $[13,52]$.

The studied peatland is not rare for the tundra ecoclimatic zone: The peat deposit thickness obviously exceeds $5 \mathrm{~m}$ and contains ice wedges with a vein height of 3-4 m. Similar thick polygonal peatlands were described earlier in lacustrine-bog depressions in the sites to the North, within the Yamal and Gydansky peninsulas [3-5].

\subsection{Soil Sampling and Laboratory Analyses}

In the field, geobotanical descriptions were carried out according to generally accepted methodology $[53,54]$. Soils were collected with a vertical resolution of $5-7 \mathrm{~cm}$. The 
determination of soil types and the indexing of soil horizons were classified according to the International Correlation Base of Soil Resources [34]. In permafrost layers (PL), samples were collected using the method of manual drilling (a steel pipe hammered into the ground). In the active layer (AL), peat samples were taken in fixed-volume $\left(503 \mathrm{~cm}^{3}\right)$ cylinders inserted horizontally into the wall of a soil section. For peat and carbon accumulation calculations, dry bulk density $\left(\mathrm{g} \mathrm{cm}^{-3}\right)$ was measured contiguously for every $5-7 \mathrm{~cm}$ after freeze-drying volumetric subsamples and by dividing the dry mass $(\mathrm{g})$ by the peat fresh volume $\left(\mathrm{cm}^{3}\right)$. Carbon and nitrogen $(\mathrm{C} / \mathrm{N})$ content measurements were performed at 5-7-cm intervals, at the Institute of Biology (Syktyvkar, Russia), using an automatic $\mathrm{CHN}(\mathrm{S}, \mathrm{O})$-analyzer EA-1110 (Carlo Erba CE Instruments, Milan, Italy) and these results were applied to calculate average carbon values. To estimate the temporal variations in apparent carbon accumulation rates (ACAR, $\mathrm{g} \mathrm{C} \mathrm{m}^{-2} \mathrm{yr}^{-1}$ ), the carbon mass of every $1-\mathrm{cm}$ increment $\left(\mathrm{g} \mathrm{m}^{-3}\right)$ was multiplied by the corresponding vertical peat accumulation rate $\left(\mathrm{m} \mathrm{yr}^{-1}\right)$ based on the age depth models.

Plant macrofossil analysis was performed at the Institute of Biology Karelian Science Center, Russian Academy of Sciences. The samples were examined after deflocculating peat of known volume $\left(5-20 \mathrm{~cm}^{3}\right)$ with $5 \% \mathrm{KOH}$ and sieving $(150-\mu \mathrm{m}$ mesh) to remove fine detritus; remains were identified under a stereo binocular (25-40 $\times$ magnification) using reference literature [55]. Sphagnum species were identified by their leaf morphology [56] under the microscope (100-400 $\times$ magnification). The abundance of selected species of plant macrofossils was calculated as a volume percentage of the total macrofossil assemblage. Visualization of gross stratigraphy and plant macrofossils were performed using the software «Korpi» (version 1.0) [57].

Spore-pollen analysis was done at the Institute of Geology of the Federal Research Center of the Komi Scientific Center of the Ural Branch of the Russian Academy of Sciences. Chemical processing of soil samples for palynological studies was carried out using standard techniques: alkaline Post and separation Grichuk, as well as Erdtman's acetolysis technique [58]. Spores and pollen were identified using a digital biological microscope "Motic BA 300 (420× magnification). Spore-pollen diagrams were compiled using the "TILIA" software (version 1.7.16). Interpretation and calculation of the results of the sporepollen associations were calculated in a group way. Spores and pollen in the spectra were combined into groups (pollen of trees and shrubs, grass pollen, spores), then the percentage of spore species and pollen grains was determined from $100 \%$ of the marked forms.

For radiocarbon $\left({ }^{14} \mathrm{C}\right)$ analysis of bulk $\mathrm{SOC}$, roots were removed under a microscope. The samples were treated with the standard method ABOx [59] at the Institute of Archaeology and Ethnography, Siberian Branch of Russian Academy of Science. The ${ }^{14} \mathrm{C}$ concentration using accelerator mass spectrometry was measured at the Institute of $\mathrm{Nu}$ clear Physics of the Siberian Branch of the Russian Academy of Sciences. The results were calibrated by CALIBRE software (version 8.2, ${ }^{14}$ Chrono Centre, Queens University, Belfast) and IntCal20 calibration curve, and expressed in (median) calendar years before the present (cal BP; BP = AD 1950) (Appendix B: Figure A2) [60].

The permafrost table depth and the boundaries of the lithological contacts of the polygonal peatland were determined by the method of ground-penetrating radar sounding using a Zond-12E GPR (Radar Systems, Inc., Riga, Latvia) with a 300-MHz surface-shielded antenna connected to radar [16].

\section{Conclusions}

The paleoreconstruction carried out using spore-pollen and radiocarbon methods describes the development of a thick arctic peatland during the Holocene, including changes of vegetation cover, hydrological regime, and carbon accumulation. It shows that the peat accumulation began about 9814 cal. yr. BP, in the Late Preboreal (PB-2), at a rate of 1 to $1.5 \mathrm{~mm} / \mathrm{yr}$. During the Boreal, between 9000-8000 cal. yr. BP, less intensive peat accumulation continued $(0.7 \mathrm{~mm} / \mathrm{yr})$. In the Atlantic, peat accumulation at first slowed down considerably: since 7749 cal. yr. BP, down to $0.26 \mathrm{~mm} / \mathrm{yr}$; since 6801 to $5657 \mathrm{BP}$, 
down to $0.13 \mathrm{~mm} / \mathrm{yr}$; and then it practically stopped. Compared to the tundra of the European Northeast, where, during the Holocene climate warming, the soil-geocryological complexes of peatlands repeatedly thawed, the soils of the studied peatland remained stable. Even taking into account the ongoing and projected climate changes, when both temperature and precipitation could increase all over region, arctic peatlands in continuous permafrost will remain protected from degradation. In case the hydrological regime is disturbed under anthropogenic changes, a rapid (over several years) degradation of permafrost and soil-geocryological complexes of polygonal peatlands will occur. Such changes might be irreversible and significantly transform the carbon balance of the region.

Author Contributions: Conceptualization, A.P.; investigation, A.P., S.L. and D.K.; methodology, T.M.-V. and D.K.; writing-original draft preparation, A.P. and T.M.-V.; formal analysis, T.M.-V. and D.K.; project administration, A.P. and S.L; graphical abstract-S.L. All together we discussed the obtained data and corrected the text. All authors have read and agreed to the published version of the manuscript.

Funding: The study was supported by the Russian Foundation for Basic Research No. 20-34-70005 (CITiS No. AAAA-A19-119121790049-4), the Russian Science Foundation (RSF) project No. 18-7710045, and the Federal budget. The study was partly carried out using the research equipment of the Unique Research Installation "System of experimental bases located along the latitudinal gradient" TSU with financial support from the Ministry of Education and Science of Russia (RF2296.61321X0043, agreement No. 075-15-2021-672).

Institutional Review Board Statement: Not applicable.

Informed Consent Statement: Not applicable.

Data Availability Statement: The datasets used during the current study are available from the corresponding author on reasonable request.

Acknowledgments: We thank anonymous reviewers and editors for their very constructive comments on the manuscript.

Conflicts of Interest: The authors declare no conflict of interest. The funders had no role in the design of the study; in the collection, analyses, or interpretation of data; in the writing of the manuscript; or in the decision to publish the results.

\section{Appendix A}

Morphological description of peat soil in polygon (TZ)

O0-5-brown (7.5YR4/3) dwarf shrub-hypnum peaty litter, intertwined with roots, the transition is clear in color and degree of decomposition.

$\mathrm{T}_{1}$ 5-10-brown (7.5YR4/3) dwarf shrub-sphagnum transitional peat, moist, $\mathrm{R}=45-50 \%$.

$\mathrm{T}_{2}$ 10-15-dark brown (7.5YR2.5/3) dwarf shrub-sphagnum transitional peat, moist, slightly compacted, $\mathrm{R}=40 \%$.

$\mathrm{T}_{3}$ 15-20-light brown (7.5YR4/6) dwarf shrub-grass-sphagnum transitional peat, moist, compacted, with many visible, weakly decomposed plant residues, $\mathrm{R}=30 \%$.

$\mathrm{T}_{4}$ 20-25-light brown (7.5YR4/6) dwarf shrub-moss fen peat, moist, dense, $\mathrm{R}=35 \%$.

$\mathrm{T}_{5}$ 25-35-brown (7.5YR4/3) grass-moss fen peat, moist, dense, from $30 \mathrm{~cm}$ with numerous poorly decomposed Salix residues, $\mathrm{R}=25-30 \%$.

$\mathrm{T}_{6}$ 35-40-light brown (7.5YR4/6) grass-hypnum fen peat, frozen, $\mathrm{R}=30 \%$.

$\mathrm{T}_{7}$ 40-60-brown (7.5YR4/3) horsetail-sphagnum fen peat, $\mathrm{R}=30-35 \%$.

$\mathrm{T}_{8}$ 60-66-dark brown (7.5YR2.5/3) grass-moss fen peat, $\mathrm{R}=35 \%$.

$\mathrm{T}_{9}$ 66-76-dark brown (7.5YR2.5/3) horsetail-grass fen peat, $\mathrm{R}=30 \%$.

$\mathrm{T}_{10}$ 76-107-brown (7.5YR4/3) horsetail-hypnum fen peat, $\mathrm{R}=30-35 \%$.

$\mathrm{T}_{11}$ 107-120-brown (7.5YR4/3) horsetail-sphagnum fen peat, $\mathrm{R}=25-30 \%$.

$\mathrm{T}_{12}$ 120-125-light brown (7.5YR4/6) grass-hypnum fen peat, $\mathrm{R}=30-35 \%$.

$\mathrm{T}_{13}$ 125-130-brown (7.5YR4/3) sphagnum-horsetail fen peat, $\mathrm{R}=30-35 \%$.

$\mathrm{T}_{14}$ 130-137-brown (7.5YR4/3) hypnum fen peat, $\mathrm{R}=35 \%$.

$\mathrm{T}_{15}$ 137-142-brown (7.5YR4/3) horsetail-hypnum fen peat, $\mathrm{R}=30-35 \%$. 
$\mathrm{T}_{16}$ 142-147-brown (7.5YR4/3) grass-moss fen peat, $\mathrm{R}=35 \%$.

$\mathrm{T}_{17}$ 147-153-light brown (7.5YR4/6) grass-hypnum fen peat, $\mathrm{R}=35 \%$.

$\mathrm{T}_{18}$ 153-158-dark brown (7.5YR2.5/3) horsetail-hypnum fen peat, $\mathrm{R}=35 \%$.

$\mathrm{T}_{19}$ 158-176-brown (7.5YR4/3) grass-horsetail fen peat, $\mathrm{R}=35-40 \%$.

$\mathrm{T}_{20}$ 176-200-brown (7.5YR4/3) grass-sphagnum fen peat, $\mathrm{R}=25-35 \%$.

$\mathrm{T}_{21}$ 200-207-light brown (7.5YR4/6) grass-horsetail-sphagnum fen peat, $\mathrm{R}=30 \%$.

$\mathrm{T}_{22}$ 207-212-light brown (7.5YR4/6) grass-horsetail fen peat, $\mathrm{R}=35 \%$.

$\mathrm{T}_{23}$ 212-231-brown (7.5YR4/3) horsetail-sphagnum fen peat, $\mathrm{R}=35 \%$.

$\mathrm{T}_{24}$ 231-242-brown (7.5YR4/3) grass-hypnum fen peat, $\mathrm{R}=35 \%$.

$\mathrm{T}_{25}$ 242-260-brown (7.5YR4/3) sedge-moss fen peat, $\mathrm{R}=35-40 \%$.

$\mathrm{T}_{26}$ 260-264-dark brown (7.5YR2.5/3) sedge-hypnum fen peat, $\mathrm{R}=35-40 \%$.

$\mathrm{T}_{27}$ 264-270-dark brown (7.5YR2.5/3) grass-hypnum fen peat, $\mathrm{R}=35-40 \%$.

Soil: Ombric Sapric CryicHistosols (Hyperorganic)

Morphological description of peat soil in interpolygonal crack (TZf)

$\mathrm{T}_{1}$ 0-5-light yellowish-brown (10YR7/8) shrub-sphagnum fen peat, moist, loose, $\mathrm{R}=5 \%$.

$\mathrm{T}_{2}$ 5-30-yellowish-brown (10YR6/6) sphagnum fen peat, moist, loose, rare roots of dwarf shrubs, $R=5-10 \%$.

$\mathrm{T}_{3}$ 30-33-light brown (7.5YR4/6) hypnum-sphagnum transitional peat, laminated, water saturated, $\mathrm{R}=15 \%$.

$\mathrm{T}_{4}$ 33-37-brown (7.5YR4/3) dwarf shrub-hypnum transitional peat, frozen, $\mathrm{R}=25 \%$.

$\mathrm{T}_{5}$ 37-45-brown (7.5YR4/3) dwarf shrub-grass transitional peat, frozen, $\mathrm{R}=40 \%$.

$\mathrm{T}_{6} 45-60$ - dark brown (7.5YR2.5/3) sphagnum fen peat, $\mathrm{R}=15-25 \%$.

A space of $60-65 \mathrm{~cm}$ is filled with a horizontal ice vein, which expands to $20 \mathrm{~cm}$ on the left wall and turns into a large block of ice wedge (over $3 \mathrm{~m}$ wide).

$\mathrm{T}_{7}$ 65-100—dark brown (7.5YR2.5/3) grass fen peat, $\mathrm{R}=25 \%$.

Soil: Hemic Muusic Histosols.

\section{Appendix B}

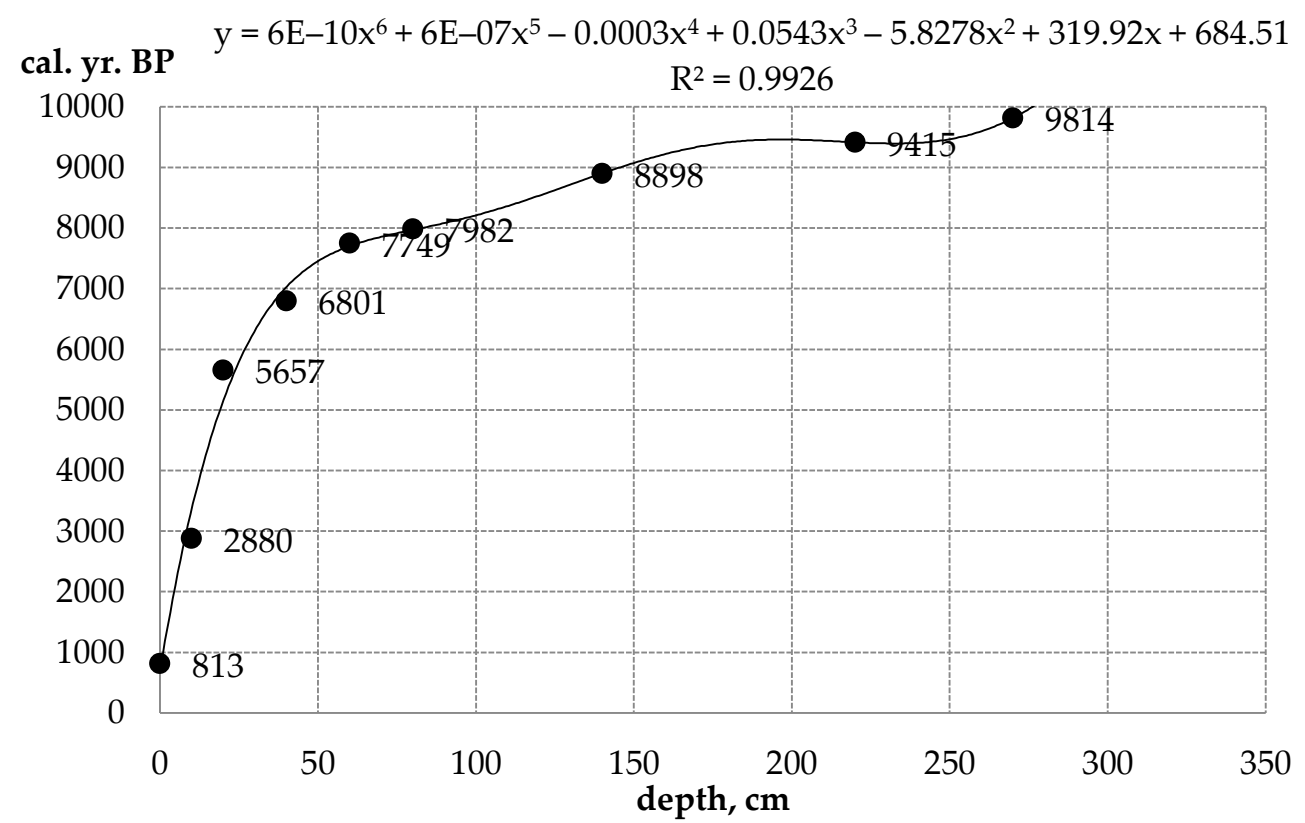

Figure A1. Radiocarbon age model of TZ. 


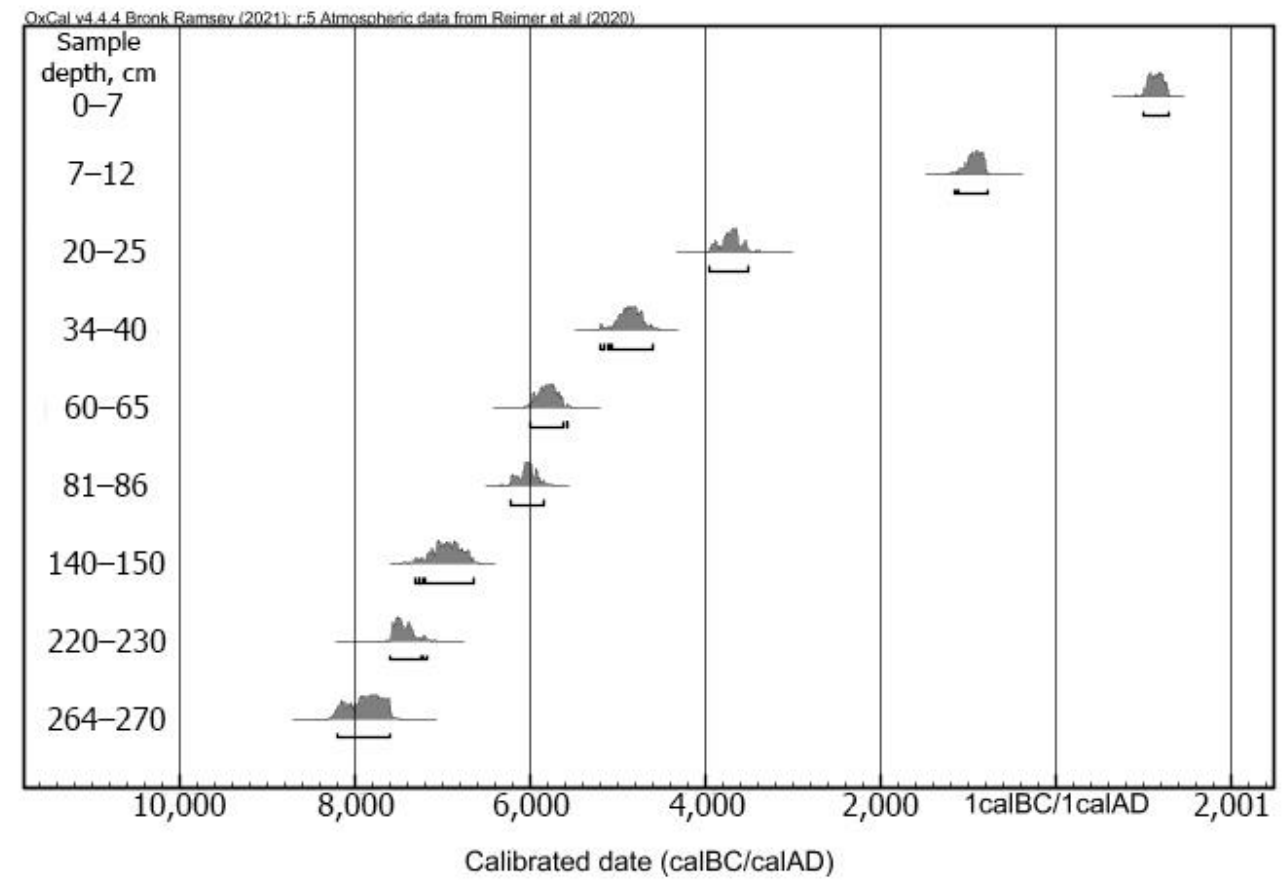

Figure A2. Multiple plot dates of TZ.

\section{References}

1. Limpens, J.; Berendse, F.; Blodau, C.; Canadell, J.G.; Freeman, C.; Holden, J.; Roulet, N.; Rydin, H.; Schaepman-Strub, G. Peatlands and the carbon cycle: From local processes to global implications-A synthesis. Biogeosciences 2008, 5, 1475-1491. [CrossRef]

2. Sheng, Y.; Smith, L.C.; MacDonald, G.M.; Kremenetski, K.V.; Frey, K.E.; Velichko, A.A.; Lee, M.; Beilmannr, D.W.; Dubinin, P. A high-resolution GIS-based inventory of the west Siberian peat carbon pool. Glob. Biogeochem. Cycles 2004, 18, GB3004. [CrossRef]

3. Loiko, S.; Raudina, T.; Lim, A.; Kuzmina, D.; Kulizhskiy, S.; Pokrovsky, O. Microtopography Controls of Carbon and Related Elements Distribution in the West Siberian Frozen Bogs. Geosciences 2019, 9, 291. [CrossRef]

4. Vasil'chuk, Y.; Vasil'chuk, A. Thick polygonal peatlands in continuous permafrost of West Siberia. Earth's Cryosph. 2016, 20, 3-13. [CrossRef]

5. Fotiev, S.M. Arctic peatlands of the Yamal-Gydan province of Western Siberia. Earth's Cryosph. 2017, 21, 75-83. [CrossRef]

6. Veremeeva, A.; Nitze, I.; Günther, F.; Grosse, G.; Rivkina, E. Geomorphological and Climatic Drivers of Thermokarst Lake Area Increase Trend (1999-2018) in the Kolyma Lowland Yedoma Region, North-Eastern Siberia. Remote Sens. 2021, 13, 178. [CrossRef]

7. Loiko, S.; Klimova, N.; Kuzmina, D.; Pokrovsky, O. Lake Drainage in Permafrost Regions Produces Variable Plant Communities of High Biomass and Productivity. Plants 2020, 9, 867. [CrossRef] [PubMed]

8. Magnússon, R.; Limpens, J.; van Huissteden, J.; Kleijn, D.; Maximov, T.C.; Rotbarth, R.; Sass-Klaassen, U.G.W.; Heijmans, M.M.P.D. Rapid Vegetation Succession and Coupled Permafrost Dynamics in Arctic Thaw Ponds in the Siberian Lowland Tundra. J. Geophys. Res. Biogeosci. 2020, 125, e2019JG005618. [CrossRef]

9. Vasiliev, A.; Drozdov, D.; Gravis, A.; Malkova, G.; Nyland, K.; Streletskiy, D. Permafrost degradation in the Western Russian Arctic. Res. Lett. 2020, 15, 045001. [CrossRef]

10. Inisheva, L.I.; Kobak, K.I.; Turchinovich, I.E. Evolution of the paludification process, and carbon accumulation rate in bog ecosystems of Russia. Geogr. Nat. Resour. 2013, 34, 246-253. [CrossRef]

11. Kumpula, T.; Forbes, B.C.; Stammler, F.; Meschtyb, N. Dynamics of a Coupled System: Multi-Resolution Remote Sensing in Assessing Social-Ecological Responses during 25 Years of Gas Field Development in Arctic Russia. Remote Sens. 2012, 4, 1046-1068. [CrossRef]

12. Ardelean, F.; Onaca, A.; Chețan, M.-A.; Dornik, A.; Georgievski, G.; Hagemann, S.; Timofte, F.; Berzescu, O. Assessment of Spatio-Temporal Landscape Changes from VHR Images in Three Different Permafrost Areas in the Western Russian Arctic. Remote Sens. 2020, 12, 3999. [CrossRef]

13. Babkin, E.M.; Khomutov, A.V.; Dvornikov, Y.A.; Khairullin, R.R.; Babkina, E.A. Relief changes of the peat plateau with melting of polygonal-wedge ice in the northern part of the Pur-Taz Interfluve. Reg. Environ. Issues 2018, 4, 115-119. (In Russian) [CrossRef]

14. Kaverin, D.A.; Pastukhov, A.V.; Novakovsky, A.B.; Biasi, K.; Maruschak, M.; Elsakov, V.V. Landscape and climatic factors impacting the thaw depth in soils of permafrost peat plateaus (on the example of CALM R52 site). Earth's Cryosph. 2019, 23, 53-60. [CrossRef]

15. Tikhonravova, Y.V.; Slagoda, E.A.; Rogov, V.V.; Butakov, V.I.; Lupachev, A.V.; Kuznetsova, A.O.; Simonova, G.V. Heterogeneous ices in ice wedges structure on the Pur-Taz interfluve peatlands of the north of West Siberia. Ice Snow 2020, 60, 225-238. (In Russian) [CrossRef] 
16. Kaverin, D.A.; Khilko, A.V.; Pastukhov, A.V. Application of high-frequency ground penetrating radar to investigations of permafrost-affected soils of peat plateaus (European Northeast of Russia). Earth's Cryosph. 2018, 22, 75-83. [CrossRef]

17. Raudina, T.V.; Loiko, S.V. Properties and major element concentrations in peat profiles of the polygonal frozen bog in Western Siberia. IOP Conf. Ser. Earth Environ. Sci. 2019, 400, 012009. [CrossRef]

18. Pastukhov, A.; Loiko, S.; Kaverin, D. Polycyclic aromatic hydrocarbons in permafrost peatlands. Sci. Rep. 2021, 11, 18878. [CrossRef]

19. Pastukhov, A.V.; Kaverin, D.A. Ecological state of peat plateaus in northeastern European Russia. Russ. J. Ecol. 2016, 47, 125-132. [CrossRef]

20. Preis, Y.I.; Simonova, G.V.; Slagoda, E.A. Detailed Stratigraphy and Dynamics of Central Yamal Khasyrey during the Late Holocene. Bull. Tomsk Polytech. Univ. Geo Assets Eng. 2016, 327, 35-49. (In Russian)

21. Pastukhov, A.V.; Marchenko-Vagapova, T.I.; Kaverin, D.A.; Kulizhskii, S.P.; Kuznetsov, O.L.; Panov, V.S. Dynamics of peat plateau near the southern boundary of the east European permafrost zone. Eur. Soil Sci. 2017, 50, 526-538. [CrossRef]

22. Sizov, O.S.; Yurtaev, A.A.; Soromotin, A.V.; Koptseva, E.M.; Volvakh, A.O.; Abakumov, E.V.; Berdnikov, N.M.; Prikhodko, N.V.; Guryev, D.S. Reconstruction of the Formation History of the Peat Plateau in the Lower Reaches of the Nadym River. Earth's Cryosph. 2021, 25, 3-13. [CrossRef]

23. Peteet, D.; Andreev, A.; Bardeen, W.; Mistretta, F. Long-term Arctic peatland dynamics, vegetation and climate history of the Pur-Taz region, Western Siberia. Boreas 1998, 27, 115-126. [CrossRef]

24. Panova, N.K.; Trofimova, S.S.; Antipina, T.G.; Zinoviev, E.V.; Gileva, A.V.; Erokhinb, N.G. Holocene Dynamics of Vegetation and Ecological Conditions in the Southern Yamal Peninsula According to the Results of Comprehensive Analysis of a Relict Peat Bog Deposit. Russ. J. Ecol. 2010, 1, 20-27. [CrossRef]

25. Borgmark, A. Holocene climate variability and periodicities in south-central Sweden, as interpreted from peat humification analysis. Holocene 2005, 15, 387-395. [CrossRef]

26. Yeloff, D.; Mauquoy, D. The influence of vegetation composition on peat humification: Implications for palaeoclimatic studies. Boreas 2006, 35, 662-673. [CrossRef]

27. Zoltai, S. Permafrost distribution in peatlands of west-central Canada during the Holocene warm period 6000 years BP. Geogr. Phys. Quatern. 1995, 49, 45-54. [CrossRef]

28. Seppälä, M. Surface abrasion of palsas by wind action in Finnish Lapland. Geomorphology 2003, 52, 141-148. [CrossRef]

29. Seppälä, M. Synthesis of studies of palsa formation underlining the importance of local environmental and physical characteristics. Quat. Res. 2011, 75, 366-370. [CrossRef]

30. Seppälä, M. Physical and environmental properties of palsa formations. In Climate Change Impacts on Sub-Arctic Palsa Mires and Greenhouse Gas Feedbacks; Fronzek, S., Johansson, M., Christensen, T.R., Carter, T.R., Friborg, T., Luoto, M., Eds.; Reports of Finnish Environment Institute: Helsinki, Finland, 2009; Volume 3, pp. 12-14. Available online: https:/ / www.scopus.com/record/display. uri?eid=2-s2.0-85088652223\&origin=inward (accessed on 18 October 2021).

31. Dobinski, W. Permafrost active layer. Earth-Sci. Rev. 2020, 208, 103301. [CrossRef]

32. Pyavchenko, N.I. Bugristyye Torfyaniki (Peat Plateaus); Academy of Sciences of the USSR: Moscow, Russia, 1955; p. 277, (In Russian). Available online: https:/ / search.rsl.ru/ru/record/01005904790 (accessed on 18 October 2021).

33. Piavchenko, N.I. Lesnoye Bolotovedeniye (Forest Bog Science); Academy of Sciences of the USSR: Moscow, Russia, 1963; p. 193, (In Russian). Available online: https:/ / search.rsl.ru/ru/record/01006159267 (accessed on 18 October 2021).

34. IUSS Working Group WRB. World Reference Base for Soil Resources 2014: Update 2015; Rep. 106; Food and Agriculture Organization of the United Nations: Rome, Italy, 2015; p. 203. Available online: http:/ / www.fao.org/3/a-i3794en.pdf (accessed on 18 October 2021).

35. Tikhonravova, Y.V. Osobennosti Stroyeniya Poligonal'no-zhil'nykh l'dov Severa Gydanskogo Poluostrova i Pur-Tazovskogo Mezhdurech'ya (Features of the Structure of Polygonal-Veined Ice in the North of the Gydan Peninsula and the Pur-Taz Interfluve). Ph.D. Thesis, Tyumen, Russia, 2019; p. 24. (In Russian). Available online: https://www.dissercat.com/content/osobennostistroeniya-poligonalno-zhilnykh-ldov-severa-gydanskogo-poluostrova-i-pur-tazovsko (accessed on 18 October 2021).

36. Routh, J.; Hugelius, G.; Kuhry, P.; Filley, T.; Tillman, P.K.; Becher, M.; Crill, P. Multi-proxy study of soil organic matter dynamics in permafrost peat deposits reveal vulnerability to climate change in the European Russian Arctic. Chem. Geol. 2014, 368, 104-117. [CrossRef]

37. Blyakharchuk, T.A. Western Siberia, a review of Holocene climatic changes. J. Siber. Fed. Univ. 2009, 2, 4-12. Available online: http:/ / elib.sfu-kras.ru/bitstream/handle/2311/1221/01_Blyakharchuk.pdf?sequence=1 (accessed on 18 October 2021).

38. Vasilchuk, A.K. Palynospectra and chronology of the Holocene polygonal-vein complexes of Yamal. Arktika i Antarktika (Arct. Antarct.) 2017, 1, 84-109. (In Russian) [CrossRef]

39. Groisman, P.Y.; Blyakharchuk, T.A.; Chernokulsky, A.V.; Arzhanov, M.M.; Marchesini, L.B.; Bogdanova, E.G.; Borzenkova, I.I.; Bulygina, O.N.; Karpenko, A.A.; Karpenko, L.V.; et al. Climate Changes in Siberia. In Regional Environmental Changes in Siberia and Their Global Consequences; Groisman, P., Gutman, G., Eds.; Springer: Dordrecht, The Netherlands, 2013; pp. 57-109. [CrossRef]

40. Clymo, R.S.; Turunen, J.; Tolonen, K. Carbon accumulation in peatland. Oikos 1998, 81, 368-388. [CrossRef]

41. Tsyganov, A.N.; Zarov, E.A.; Mazei, Y.A.; Kulkov, M.G.; Babeshko, K.V.; Yushkovets, S.Y.; Payne, R.J.; Ratcliffe, J.L.; Fatyunina, Y.A.; Zazovskaya, E.P.; et al. Key periods of peatland development and environmental changes in the middle taiga zone of Western Siberia during the Holocene. Ambio 2021, 50, 1896-1909. [CrossRef] [PubMed]

42. Knoblauch, C.; Beer, C.; Liebner, S.; Grigoriev, M.N.; Pfeiffer, E.-M. Methane production as key to the greenhouse gas budget of thawing permafrost. Nat. Clim. Chang. 2018, 8, 309-312. [CrossRef] 
43. Myhre, G.; Shindell, D.; Breon, F.M.; Collins, W.; Fuglestvedt, J.; Huang, J.; Koch, D.; Lamarque, J.-F.; Lee, D.; Mendoza, B.; et al. Anthropogenic and Natural Radiative Forcing. In Climate Change 2013: The Physical Science Basis. Contributions of Working Group I to the Fifth Assessment Report of the Intergovernmental Panel on Climate Change; Stocker, T.F., Qin, D., Plattner, G.-K., Tignor, M., Allen, S.K., Boschung, J., Nauels, A., Xia, Y., Bex, V., Midgley, P.M.., Eds.; Cambridge University: Cambridge, UK; New York, NY, USA, 2013; pp. 659-740. Available online: https://www.ipcc.ch/site/assets/uploads/2018/02/WG1AR5_Chapter08_FINAL.pdf (accessed on 18 October 2021).

44. Novikov, S.M. (Ed.) Gidrologiya Zabolochennykh Territoriy Zony Mnogoletney Merzloty Zapadnoy Sibiri (Hydrology of Wetlands in the Permafrost Zone of Western Siberia); VVM: St. Petersburg, Russia, 2009; p. 536, (In Russian). Available online: http: //www.hydrology.ru/sites/default/files/Books/batuev.pdf (accessed on 18 October 2021).

45. Fortier, R.; LeBlanc, A.-M.; Yu, W. Impacts of permafrost degradation on a road embankment at Umiujaq in Nunavik(Quebec), Canada. Can. Geotechn. J. 2011, 48, 720-740. [CrossRef]

46. Shur, Y.L.; Jorgenson, M.T. Patterns of permafrost formation and degradation in relation to climate and ecosystems. Permafr. Periglac. Process. 2007, 18, 7-19. [CrossRef]

47. Matveeva, N.V. Zonal'nost' v rastitel'nom pokrove Arktiki (Zonation in plant cover of the Arctic); S.-Peterburg, Russia. Trudy BIN RAN 1998, 22, 220. (In Russian). Available online: https:/ /booksee.org/book/764271 (accessed on 18 October 2021).

48. Climate Database Gaz-Sale. (In Russian). Available online: https://ru.climate-data.org/\%D0\%B0\%D0\%B7\%D0\%B8\%D1\%8 F/\%D1\%80\%D0\%BE\%D1\%81\%D1\%81\%D0\%B8\%D0\%B9\%D1\%81\%D0\%BA\%D0\%B0\%D1\%8F-\%D1\%84\%D0\%B5\%D0\%B4 $\% \mathrm{D} 0 \% \mathrm{~B} 5 \% \mathrm{D} 1 \% 80 \% \mathrm{D} 0 \% \mathrm{~B} 0 \% \mathrm{D} 1 \% 86 \% \mathrm{D} 0 \% \mathrm{~B} 8 \% \mathrm{D} 1 \% 8 \mathrm{~F} / \% \mathrm{D} 1 \% 8 \mathrm{~F} \% \mathrm{D} 0 \% \mathrm{BC} \% \mathrm{D} 0 \% \mathrm{~B} 0 \% \mathrm{D} 0 \% \mathrm{BB} \% \mathrm{D} 0 \% \mathrm{BE}-\% \mathrm{D} 0 \% \mathrm{BD} \% \mathrm{D} 0 \% \mathrm{~B} 5$

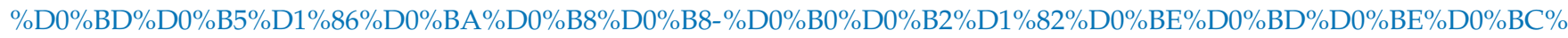
D0\%BD \%D1\%8B\%D0\%B8-\%D0\%BE\%D0\%BA\%D1\%80\%D1\%83\%D0\%B3/\%D0\%B3\%D0\%B0\%D0\%B7-\%D1\%81\%D0\%B0\%D0 $\%$ BB\%D0\%B5-713070/ (accessed on 18 October 2021).

49. Skhema territorial'nogo planirovaniya Tazovskogo rayona. Poyasnitel'naya zapiska (Spatial planning scheme for the Tazovsky district. Explanatory note). Magnitogorsk 2015, 2, 375. (In Russian). Available online: https://tasu.ru/gradostroitelnayadeyatelnost/dokumenty-territorialnogo-planirovaniya/skhema-territorialnogo-planirovaniya / (accessed on 19 October 2021).

50. Geocryological Map of Russia and Neighbouring Republics, 1:2,500,000 Scale; The English-Language Edition; Moscow State University: Moscow, Russia; Russian Ministry of Geology: Moscow, Russia, 1999. [CrossRef]

51. Golubyatnikov, L.L.; Zarov, E.A.; Kazantsev, V.S.; Filippov, I.V.; Gavrilov, G.O. Analysis of landscape structure in the Tundra Zone for Western Siberia based on satellite data. Izv. Atmos. Ocean. Phys. 2015, 51, 969-978. [CrossRef]

52. Khomutov, A.V.; Babkin, E.M.; Tikhonravova, Y.V.; Khairullin, R.R.; Dvornikov, Y.A.; Babkina, E.A.; Kaverin, D.A.; Gubarkov, A.A.; Slagoda, E.A.A.; Sadurtdinov, M.R.; et al. Complex studies of the cryolithozone of the northeastern part of the Pur-Taz Interfluve. Scient. Bull. YNAO 2019, 102, 53-64. (In Russian) [CrossRef]

53. Shennikov, A.P. Vvedeniye v Geobotaniku (Introduction to Geobotany); Leningrad State University: Leningrad, Russia, 1964; p. 447, (In Russian). Available online: https:/ / booksee.org/book/545886 (accessed on 18 October 2021).

54. Ipatov, V.S.; Kirikova, L.A. Phytocenology: Textbook; Publishing House of St. Petersburg State University: St. Petersburg, Russia, 1997; p. 316, (In Russian). Available online: https://geobotany.bio.spbu.ru/publish\%20dep/phytocenology1997.pdf (accessed on 18 October 2021).

55. Mossberg, B.; Stenberg, L. Den. Nya Nordiska Floran; Wahlström \& Widstrand: Stockholm, Sweden, 2003; p. 928, (In Norwegian). Available online: https:/ / www.bonnierfakta.se/bocker/151725/den-nya-nordiska-floran/ (accessed on 18 October 2021).

56. Laine, J.; Harju, P.; Timonen, T.; Laine, A.; Tuittila, E.S.; Minkkinen, K.; Vasander, H. The Intricate Beauty of Sphagnum Mosses: A Finnish Guide to Identification; University of Helsinki Department of Forest Sciences Publications: Helsinki, Finland, 2011 ; p. 191. Available online: https: / www.nhbs.com/the-intricate-beauty-of-sphagnum-mosses-book-2 (accessed on 18 October 2021).

57. Kutenkov, S.A. The computer program «Korpi» for the construction of stratigraphic charts of peat composition. Trans. Karel. Res. Cent. Russ. Acad. Sci. 2013, 6, 171-176. (In Russian). Available online: https://www.elibrary.ru/item.asp?id=21112812 (accessed on 18 October 2021).

58. Pyl'tsevoy Analiz (Pollen Analysis); Pokrovskaya, I.M. (Ed.) Gosgeolitizdat: Moscow, Russia, 1950; p. 571, (In Russian). Available online: https:/ / search.rsl.ru/ru/record/01006012319 (accessed on 18 October 2021). (In Russian)

59. Brock, F.; Higham, T.; Ditchfield, P.; Bronk Ramsey, C. Current Pretreatment Methods for AMS Radiocarbon Dating at the Oxford Radiocarbon Accelerator Unit (ORAU). Radiocarbon 2010, 52, 103-112. [CrossRef]

60. Stuiver, M.; Reimer, P.J.; Reimer, R.W. CALIB 8.2 [WWW program]. 2021. Available online: http:/ / calib.org (accessed on 19 October 2021). 